\title{
Changes of Activity Concentration of Tritium in Water under the Air with Tritiated Water Vapor
}

\author{
Sung Paal Yim', Cheo Kyung Lee ${ }^{2}$ \\ ${ }^{1}$ Department of HANARO Management, Korea Atomic Energy Research Institute, Daejeon, Korea; ${ }^{2}$ School of Spatial Environment System Engineering, \\ Handong Global University, Pohang, Korea
}

\section{Letter}

Received February 18, 2021

Revision March 19, 2021

Accepted March 19, 2021

Corresponding author: Sung Paal Yim

Department of HANARO Management, Korea Atomic Energy Research Institute, 111 Daeduek-daero 989beon-gil, Yuseong-gu, Daejeon 34057, Korea E-mail: nspyim@kaeri.re.kr

(iD https://orcid.org/0000-0003-2373-5862

This is an open-access article distributed under the terms of the Creative Commons Attribution License (http://creativecommons.org/licenses/by-nc/4.0), which permits unrestricted use, distribution, and reproduction in any medium, provided the original work is properly cited.

Copyright $\odot 2021$ The Korean Association for Radiation Protection

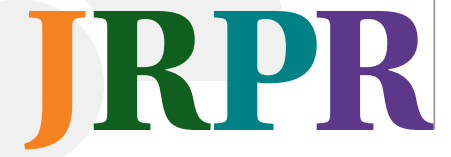

Recently, controversy continues over the cause of occurrence of tritiated water, whose activity concentration was about $7.1 \times 10^{8} \mathrm{~Bq} \cdot \mathrm{m}^{-3}$, found in a nuclear power plant in Korea. The power plant claims that the tritiated water may have been produced by the absorption of the tritiated water vapor from the air, while some suspect that it may have leaked out from the other systems [1]. We cannot hastily determine the exact cause but we have investigated the possibility that water containing initially no tritium could be changed to tritiated water with high activity concentration of tritium when it is placed in the air containing tritiated water vapor.

It has been well known since the 1960s that tritium in the air containing tritiated vapor (HTO, T is tritium or ${ }^{3} \mathrm{H}$ ) is easily transferred in water. This phenomenon has been used early for sampling of tritium in the air (known as air bubbler) [2-4] and still used today. It is also applied to respiratory masks for removing tritiated water vapor these days [5-7].

The relationship between the molar concentrations of tritium and hydrogen in the tritiated vapor of the air and those in (liquid phase) water at equilibrium is expressed by Equation (1), reported by Sepall and Mason [8], as follows:

$$
\frac{([T] /[H])_{\text {vapor }}}{([T] /[H])_{\text {water }}}=\alpha
$$

where $T$ is tritium, $H$ is hydrogen, and $\alpha$ is the partition constant (or equilibrium constant) and is 0.91 at $20^{\circ} \mathrm{C}$.

In the above equation, molar concentrations of tritium in vapor and water can be converted to the activity concentrations of tritium in vapor and water, respectively, by the following equation:

$$
[\mathrm{T}]=\frac{\mathrm{m}}{V}=\frac{A}{\lambda} \times \frac{1}{6.023 \times 10^{23}} \times \frac{1}{V}=\frac{S}{\lambda} \times \frac{1}{6.023 \times 10^{23}}
$$

where $m$ is the number of moles of tritium in vapor or water, $V$ is the volume of vapor or water, $A$ is the radioactivity of tritium in vapor or water, $\lambda$ is the decay constant of tritium, $6.023 \times 10^{23}$ is Avogadro's number, and $S$ is the activity concentration of tritium in vapor or water.

The activity concentration of tritium in the air and that in water at equilibrium are calculated by using above two equations and the result is shown in Fig. 1 . 
An air with activity concentration of $3,000 \mathrm{~Bq} \cdot \mathrm{m}^{-3}$ (release limit of tritium in air with tritiated water vapor in Korea [9]) equilibrates at $20^{\circ} \mathrm{C}$ with a water with activity concentration of $1.92 \times 10^{8} \mathrm{~Bq} \cdot \mathrm{m}^{-3}$. Also, at the same temperature, an air with activity concentration of $300,000 \mathrm{~Bq} \cdot \mathrm{m}^{-3}$ (derived concentration of tritium in air with tritiated water vapor in Korea [9]) equilibrates with a water with activity concentration of $1.92 \times 10^{10} \mathrm{~Bq} \cdot \mathrm{m}^{-3}$.

When a $1 \mathrm{~m}^{3}$ of water with no tritium is placed in certain volume of air with $50 \% \mathrm{RH}$ (relative humidity) at $20^{\circ} \mathrm{C}$ and tritiated vapor, the activity concentration of tritium in air and that in water at equilibrium after saturation by the water and tritiated water vapors are shown in Table 1.

When a $1 \mathrm{~m}^{3}$ of water with no tritium is placed in a volume of air with $50 \% \mathrm{RH}$ at $20^{\circ} \mathrm{C}$, containing tritium, the activity

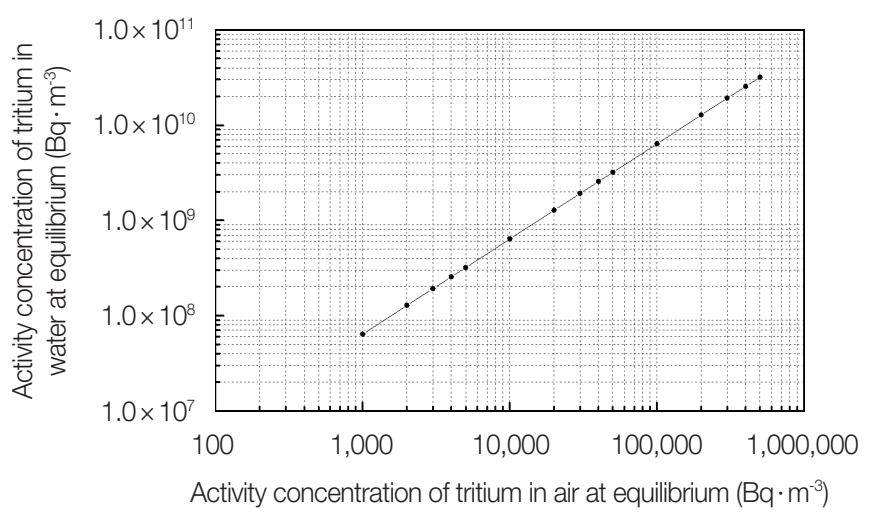

Fig. 1. Activity concentration of tritium in air and that in water at equilibrium $\left(20^{\circ} \mathrm{C}\right)$. concentration of tritium in air and that in water at equilibrium are changed with the volume of air. When volumes of air with initial activity concentration of $3,000 \mathrm{~Bq} \cdot \mathrm{m}^{-3}$ are $10 \mathrm{~m}^{3}, 100 \mathrm{~m}^{3}$, $1,000 \mathrm{~m}^{3}, 5,000 \mathrm{~m}^{3}, 10,000 \mathrm{~m}^{3}, 15,000 \mathrm{~m}^{3}$, and $20,000 \mathrm{~m}^{3}$, respectively, the activity concentrations of tritium in air at equilibrium are reduced to $0.47 \mathrm{~Bq} \cdot \mathrm{m}^{-3}, 4.7 \mathrm{~Bq} \cdot \mathrm{m}^{-3}, 47 \mathrm{~Bq} \cdot \mathrm{m}^{-3}$, $230 \mathrm{~Bq} \cdot \mathrm{m}^{-3}, 440 \mathrm{~Bq} \cdot \mathrm{m}^{-3}, 640 \mathrm{~Bq} \cdot \mathrm{m}^{-3}$, and $820 \mathrm{~Bq} \cdot \mathrm{m}^{-3}$, respectively, and those in water increase to $3.0 \times 10^{4} \mathrm{~Bq} \cdot \mathrm{m}^{-3}$, $3.0 \times 10^{5} \mathrm{~Bq} \cdot \mathrm{m}^{-3}, 3.0 \times 10^{6} \mathrm{~Bq} \cdot \mathrm{m}^{-3}, 1.5 \times 10^{7} \mathrm{~Bq} \cdot \mathrm{m}^{-3}, 2.8 \times 10^{7}$ $\mathrm{Bq} \cdot \mathrm{m}^{-3}, 4.1 \times 10^{7} \mathrm{~Bq} \cdot \mathrm{m}^{-3}$, and $5.3 \times 10^{7} \mathrm{~Bq} \cdot \mathrm{m}^{-3}$, respectively. It indicates that the activity concentration of tritium in water placed in the air of 3,000 Bq $\cdot \mathrm{m}^{-3}$ and $15,000 \mathrm{~m}^{3}$ could exceed the release limit of tritiated water in Korea $\left(4 \times 10^{7} \mathrm{~Bq} \cdot \mathrm{m}^{-3}\right)$ [9]. If the initial activity concentration of tritium in air is $300,000 \mathrm{~Bq} \cdot \mathrm{m}^{-3}$, the equilibrium activity concentration of tritium in water placed in the air of above $150 \mathrm{~m}^{3}$ exceeds the release limit of tritiated water.

Changes of the activity concentration of tritium in air and that in water at equilibrium with relative humidity at $20^{\circ} \mathrm{C}$ are shown in Table 2.

The lower the initial relative humidity of air, although the activity concentration of tritium is the same, the higher the activity concentration of tritium in air and that in water at equilibrium. The reason is that the lower the relative humidity, the more evaporation of water until it reaches the equilibrium and the volume of water decreases.

As described above, we briefly estimates the change of the activity concentration of tritium in water when the water is placed in the air containing tritiated water vapor. We have

Table 1. Activity Concentration of Tritium in Air and That in Water at Equilibriuma)

\begin{tabular}{|c|c|c|c|c|c|c|c|c|}
\hline \multirow{3}{*}{$\begin{array}{l}\text { Initial activity } \\
\text { concentration of } \\
\text { tritium in air }\left(\mathrm{Bq} \cdot \mathrm{m}^{-3}\right)\end{array}$} & \multirow{3}{*}{ Phase } & \multicolumn{7}{|c|}{ Activity concentration of tritium in air and that in water at equilibrium, $20^{\circ} \mathrm{C}\left(\mathrm{Bq} \cdot \mathrm{m}^{-3}\right)$} \\
\hline & & \multicolumn{7}{|c|}{ Volume of air $\left(m^{3}\right)$} \\
\hline & & 10 & 100 & 1,000 & 5,000 & 10,000 & 15,000 & 20,000 \\
\hline \multirow[t]{2}{*}{1,000} & Air & 0.16 & 1.6 & 16 & 76 & 150 & 210 & 270 \\
\hline & Water & $1.0 \times 10^{4}$ & $1.0 \times 10^{5}$ & $1.0 \times 10^{6}$ & $4.8 \times 10^{6}$ & $9.3 \times 10^{6}$ & $1.4 \times 10^{7}$ & $1.8 \times 10^{7}$ \\
\hline \multirow[t]{2}{*}{3,000} & Air & 0.47 & 4.7 & 47 & 230 & 440 & 640 & 820 \\
\hline & Water & $3.0 \times 10^{4}$ & $3.0 \times 10^{5}$ & $3.0 \times 10^{6}$ & $1.4 \times 10^{7}$ & $2.8 \times 10^{7}$ & $4.1 \times 10^{7}$ & $5.3 \times 10^{7}$ \\
\hline \multirow[t]{2}{*}{10,000} & Air & 1.6 & 16 & 160 & 760 & 1,500 & 2,100 & 2,700 \\
\hline & Water & $1.0 \times 10^{5}$ & $1.0 \times 10^{6}$ & $1.0 \times 10^{7}$ & $4.8 \times 10^{7}$ & $9.3 \times 10^{7}$ & $1.4 \times 10^{8}$ & $1.8 \times 10^{8}$ \\
\hline \multirow[t]{2}{*}{30,000} & Air & 4.7 & 47 & 470 & 2,200 & 4,400 & 6,400 & 8,200 \\
\hline & Water & $3.0 \times 10^{5}$ & $3.0 \times 10^{6}$ & $3.0 \times 10^{7}$ & $1.4 \times 10^{8}$ & $2.8 \times 10^{8}$ & $4.1 \times 10^{8}$ & $5.3 \times 10^{8}$ \\
\hline \multirow[t]{2}{*}{100,000} & Air & 16 & 160 & 1,600 & 7,600 & 15,000 & 21,000 & 27,000 \\
\hline & Water & $1.0 \times 10^{6}$ & $1.0 \times 10^{7}$ & $1.0 \times 10^{8}$ & $4.6 \times 10^{8}$ & $9.3 \times 10^{8}$ & $1.4 \times 10^{9}$ & $1.8 \times 10^{9}$ \\
\hline \multirow[t]{2}{*}{300,000} & Air & 47 & 470 & 4,700 & 23,000 & 44,000 & 64,000 & 82,000 \\
\hline & Water & $3.0 \times 10^{6}$ & $3.0 \times 10^{7}$ & $3.0 \times 10^{8}$ & $1.4 \times 10^{9}$ & $2.8 \times 10^{9}$ & $4.1 \times 10^{9}$ & $5.3 \times 10^{9}$ \\
\hline
\end{tabular}

a) Initial air of $50 \%$ relative humidity at $20^{\circ} \mathrm{C}$, initial volume of water of $1 \mathrm{~m}^{3}$. 
Table 2. Changes of Activity Concentration of Tritium in Air and That in Water at Equilibrium with $\mathrm{RH}$ at $20^{\circ} \mathrm{C}^{\mathrm{a}}$

\begin{tabular}{|c|c|c|c|c|c|c|c|}
\hline \multirow{4}{*}{ Volume of air $\left(m^{3}\right)$} & \multirow{4}{*}{ Phase } & \multicolumn{6}{|c|}{ Activity concentration of tritium in air and that in water at equilibrium, $20^{\circ} \mathrm{C}\left(\mathrm{Bq} \cdot \mathrm{m}^{-3}\right)$} \\
\hline & & \multicolumn{6}{|c|}{ Initial activity concentration of tritium in air } \\
\hline & & \multicolumn{3}{|c|}{$3,000 \mathrm{~Bq} \cdot \mathrm{m}^{-3}$} & \multicolumn{3}{|c|}{$300,000 \mathrm{~Bq} \cdot \mathrm{m}^{-3}$} \\
\hline & & $10 \% \mathrm{RH}$ & $50 \% \mathrm{RH}$ & $100 \% \mathrm{RH}$ & $10 \% \mathrm{RH}$ & $50 \% \mathrm{RH}$ & $100 \% \mathrm{RH}$ \\
\hline \multirow[t]{2}{*}{10} & Air & 0.47 & 0.47 & 0.47 & 47 & 47 & 47 \\
\hline & Water & $3.0 \times 10^{4}$ & $3.0 \times 10^{4}$ & $3.0 \times 10^{4}$ & $3.0 \times 10^{6}$ & $3.0 \times 10^{6}$ & $3.0 \times 10^{6}$ \\
\hline \multirow[t]{2}{*}{100} & Air & 4.7 & 4.7 & 4.7 & 470 & 470 & 470 \\
\hline & Water & $3.0 \times 10^{5}$ & $3.0 \times 10^{5}$ & $3.0 \times 10^{5}$ & $3.0 \times 10^{7}$ & $3.0 \times 10^{7}$ & $3.0 \times 10^{7}$ \\
\hline \multirow[t]{2}{*}{1,000} & Air & 47 & 47 & 46 & 4,700 & 4,700 & 4,600 \\
\hline & Water & $3.0 \times 10^{6}$ & $3.0 \times 10^{6}$ & $3.0 \times 10^{6}$ & $3.0 \times 10^{8}$ & $3.0 \times 10^{8}$ & $3.0 \times 10^{8}$ \\
\hline \multirow[t]{2}{*}{5,000} & Air & 240 & 230 & 220 & 23,000 & 23,000 & 22,000 \\
\hline & Water & $1.4 \times 10^{7}$ & $1.40 \times 10^{7}$ & $1.40 \times 10^{7}$ & $1.50 \times 10^{9}$ & $1.50 \times 10^{9}$ & $1.40 \times 10^{9}$ \\
\hline \multirow[t]{2}{*}{10,000} & Air & 470 & 440 & 410 & 47,000 & 44,000 & 40,000 \\
\hline & Water & $3.0 \times 10^{7}$ & $2.8 \times 10^{7}$ & $2.6 \times 10^{7}$ & $3.0 \times 10^{9}$ & $2.8 \times 10^{9}$ & $2.6 \times 10^{9}$ \\
\hline \multirow[t]{2}{*}{15,000} & Air & 700 & 640 & 570 & 70,000 & 64,000 & 57,000 \\
\hline & Water & $4.5 \times 10^{7}$ & $4.1 \times 10^{7}$ & $3.6 \times 10^{7}$ & $4.5 \times 10^{9}$ & $4.1 \times 10^{9}$ & $3.6 \times 10^{9}$ \\
\hline \multirow[t]{2}{*}{20,000} & Air & 940 & 820 & 720 & 94,000 & 82,000 & 72,000 \\
\hline & Water & $6.0 \times 10^{7}$ & $5.3 \times 10^{7}$ & $4.6 \times 10^{7}$ & $6.0 \times 10^{9}$ & $5.3 \times 10^{9}$ & $4.6 \times 10^{9}$ \\
\hline
\end{tabular}

$\mathrm{RH}$, relative humidity.

a)Initial volume of water of $1 \mathrm{~m}^{3}$.

confirmed that water with initially no tritium could be changed to tritiated water with high activity concentration. At present, we are planning to conduct experiments to verify that this phenomenon occurs in the field.

\section{Conflict of Interest}

No potential conflict of interest relevant to this article was reported.

\section{Author Contribution}

Methodology: SP Yim, CK Lee. Investigation: SP Yim, CK Lee. Writing - original draft: SP Yim. Writing - review \& editing: CK Lee.

\section{References}

1. Cho HH. Tritium in air of Wolsung power plant, 1,800 times, is that normal? [Internet]. Seoul, Korea: Media Today; 2021 [cited 2021 Mar 21]. Available from: http://www.mediatoday.co.kr/ news/articleView.html?idxno=211538.

2. Valentine AM. An investigation of a bubbler tritium sampler (Report No. LA-3916). Los Alamos, NM: Los Alamos Scientific
Laboratory; 1968.

3. McConnon D. The use of water as a sampling medium for tritium oxide (Report No. BNWL-CC-547). Richland, WA: Battelle Northwest Laboratory; 1970.

4. Osborne RV. Sampling for tritiated water vapor. Proceedings of the $3^{\text {rd }}$ International Congress of the International Radiation Protection Association; 1973 September 9-14; Washington, DC. p. 1428-1433.

5. Yim SP, Lim IC, Ahn GH, Seoul CW, Lee CK. Performance test of ice packed respirator for tritium removal. Proceeding of the $36^{\text {th }}$ Annual Radioactive Waste Management Symposium (WM); 2010 March 7-11; Phoenix, AZ.

6. Shin JS, Lee JK. Wet-type tritium filter cartridge. KR Patent 200472036, 2014.

7. Radiation Safety Team of Wolsung Nuclear Power Plant \#2. Introduction to performance test on tritium respirator at Wolsung Nuclear Power Plant \#2 [Internet]. Gyeongju, Korea: Wolsung Nuclear Power Plant; 2013 [cited 2021 Mar 21]. Available from: https://www.kins.re.kr/nsic_info/nsic/2013/pdf/13_5.pdf.

8. Sepall O, Mason SG. Vapor/liquid partition of tritium in tritiated water. Can J Chem. 1960;38:2024-2025.

9. Nuclear Safety and Security Commission. Standards for Radiation Protection (NSSC Notice No. 2014-034) [Internet]. Sejong, Korea: National Law Information Center; 2014 [cited 2021 Mar 21]. Available from: https://www.law.go.kr/LSW/admRulInfoP. do?admRulSeq=2100000006874\&lsId=35174\&chrClsCd=010202. 